\title{
Redactioneel
}

\section{De coördinatieregeling van omgevingsrechtelijke besluiten kan niet in de Omgevingswet worden opgenomen}

\author{
Mr. H.A.J. (Henk) Gierveld*
}

\section{Wat wil het Tijdschrift voor Omgevingsrecht bereiken met het publiceren van artikelen?}

In deze aflevering van het Tijdschrift voor Omgevingsrecht is een artikel opgenomen van Nard Beurskens en Jelmer Ypinga over de aanpassing van afdeling 3.5 van de Algemene wet bestuursrecht (Awb). ${ }^{1}$ Die aanpassing is onderdeel van het voorstel tot wijziging van de Algemene wet bestuursrecht en enkele andere wetten in verband met het nieuwe omgevingsrecht en nadeelcompensatierecht, dat op 10 juli 2019 ter overweging is toegezonden aan de Tweede Kamer. ${ }^{2}$

Het artikel bevat de geheel juiste conclusie dat de nieuwe coördinatieregeling in plaats van in de Awb beter in de Omgevingswet had kunnen worden opgenomen. Dat is wel een pittige conclusie met een hoog bijl-aan-dewortel-gehalte. Het gaat immers om een wetsvoorstel tot wijziging van de $A m b$, die nodig is om omgevingsrechtelijke besluiten te kunnen coördineren.
Elk tijdschrift - ook het Tijdschrift voor Omgevingsrecht - wil met (een goedgekozen datum van) publicatie van artikelen een bijdrage leveren aan de rechtsontwikkeling. Dat kan aan de hand van een kritische beschouwing van uitspraken van rechters, maar bijvoorbeeld ook door publicatie van de bespreking van een wetsvoorstel, zoals door Beurskens en Ypinga is gedaan. ${ }^{3}$ Het genoemd worden in een memorie van toelichting, in een toelichting van een nota van wijziging of een amendement is dan een aardige bijvangst, maar die eeuwige roem is voor weinig auteurs weggelegd. Het zou nog leuker zijn als de minister, indien die het eens zou zijn met de opmerking, dankbaar gebruik maakt van de gedane suggestie en komt met een wijziging van het voorstel, inhoudende geen wijziging van de Awb maar een wijziging van de Omgevingswet.

Helaas, ondanks de uitstekend onderbouwde conclusie zal de minister daar niks mee doen. Beter gezegd: niks mee kunnen doen. In paragraaf 5 wil ik die conclusie onderbouwen. Nu reeds als cliffhanger: het is de vraag of er bij een wet als de Omgevingswet wel mogelijkheden zijn om substantiële wijzigingen door te voeren.
Mr. H.A.J. Gierveld is voorzitter van de redactie van het Tijdschrift voor Omgevingsrecht.

1. In par. 6 wordt aandacht besteed aan de andere artikelen die opgenomen zijn in deze aflevering.

2. Kamerstukken II 2018/19, 35 256, nr. 2.
3. Een eerder artikel over toen nog de consultatieversie van de wijziging van de Awb verscheen in een eerdere aflevering van dit tijdschrift: L.R.M.A. Beurskens, J.H.N. Ypinga \& K.J. de Graaf, De Omgevingswet als aanjager voor een nieuwe coördinatieregeling in de Awb, TO 2018, afl. 2, p. 76-83. 


\section{De wijziging van afdeling 3.5 Awb als onderdeel van de stelselherziening}

Eerst wil ik het voorstel tot wijziging van de Awb plaatsen in de context van de stelselherziening. Het voorstel tot aanpassing van afdeling 3.5 van de Awb is nodig voor de inwerkingtreding van de Omgevingswet. Dat komt omdat in de Omgevingswet op diverse plaatsen verwezen wordt naar afdeling 3.5 van de Awb, waarmee niet de huidige regeling wordt bedoeld. Reeds is vooruitgelopen op de nog noodzakelijke aanpassing van de Awb om de afdeling geschikt te maken voor het kunnen coördineren van omgevingsbesluiten. Er moet nog wel een wetje door het parlement worden geloodst. Dat zal met het gebruikelijke stoom- en kokend-waterprocedé geschieden, aangezien voorkomen moet worden dat met een ondergeschikt, technisch wetsvoorstel de voorgenomen datum van inwerkingtreding in gevaar komt.

$\mathrm{Na}$ de invoeringswet en de vier aanvullingswetten is de Awb-wijziging in wezen de zesde anpassingswet. ${ }^{4}$ De stelselherziening gaat binnenkort, als vastgehouden wordt aan de datum van 1 januari 2021, haar laatste jaar in. Dat betekent dat ook voor de parlementaire behandeling van dit wetsvoorstel weinig tijd is. Gezien de omvang van dit onderdeel van het voorstel zou dat ook moeten kunnen. ${ }^{5}$ Het lijkt me nuttig - het redactioneel geeft ook de stand van zaken weer ten aanzien van de voortgang van de wetgeving - om an te geven hoeveel tijd de Tweede Kamer en de Eerste Kamer nodig heb- ben (gehad) voor de behandeling van de diverse wetsvoorstellen. ${ }^{6}$

\section{Duur van de parlementaire behandeling (stand van zaken 1 november 2019)}

Met de parlementaire behandeling van de verschillende wetten is gemiddeld genomen anderhalf jaar gemoeid. Wil de wijziging van de Awb de voorgenomen inwerkingtredingsdatum van de Omgevingswet niet in gevaar brengen, dan zal de Tweede Kamer uiterlijk begin volgend jaar het voorstel moeten aannemen. Dat lijkt me overigens goed haalbaar.

Bij brief van 29 oktober 2019 schreef minister Ollongren dat zij de Eerste Kamer vóór 2 december 2019 de integrale voortgangsbrief over de regelgeving en de implementatie van de Omgevingswet zal toezenden. ${ }^{7}$

Die brief werd geschreven onder meer naar aanleiding van een eerdere brief van de voorzitters van de EKcommissies voor IWO en EZK/LNV van 13 september 2019, waarin stond dat de commissies zich willen inspannen om de plenaire behandeling van de voorliggende wetsvoorstellen Invoeringswet Omgevingswet, Aanvullingswet bodem Omgevingswet en Aanvullingswet geluid Omgevingswet nog vóór het komende kerstreces af te ronden. De Kamer wil voor 2 december worden geïnformeerd over de uitkomsten van het overleg met de bestuurlijke partners over de vraag of inwerkingtreding van de Omgevingswet per 1 januari 2021 haalbaar is. De behandeling van de wetsvoorstellen Aanvullingswet natuur Omgevingswet en Aanvullingswet grondeigendom Omgevingswet kan eerst begin maart 2020 worden afgerond.

\section{De datum van 3 december 2019}

De Eerste Kamer beoordeelt op 3 december 2019 of het haalbaar is nog in 2019 over te gaan tot plenaire behandeling van de wetsvoorstellen Invoeringswet Omgevingswet, Aanvullingswet bodem Omgevingswet en Aanvullingswet geluid Omgevingswet. In het kader van de beperkte ruimte van een redactioneel heb ik me geconcentreerd op de stand van zaken ten aanzien van de wetgeving. Ten overvloede: er zijn ook nog aanpassingen van de vier AMvB's voorgehangen. Daarvan

6. In de vorige aflevering van dit tijdschrift is de voortgang van de stelselherziening beschreven met als einddatum 15 september 2019: H.W. de Vos, De stand van de stelselherziening: het primaat bij de senaat, TO 2019, afl. 3, p. 69-74

7. Kamerstukken I 2019/20, 34 986, L. Zie ook Kamerstukken I 2018/19, 33 118, AU, en Kamerstukken I 2018/19, 33 118, AV. 
Stelselherziening omgevingsrecht

\begin{tabular}{|c|c|c|c|c|c|}
\hline Wet (Kamerstukken) & Indiening TK & Aanvaarding TK & Maanden* & Aanvaarding EK & Maanden \\
\hline Omgevingswet (33962) & $16-06-2014$ & 01-07-2015 & 12,5 & $22-03-2016$ & 9,5 \\
\hline Aanvw. bodem (34864) & $22-01-2018$ & $18-12-2018$ & 11 & $12-2019 ?$ & $12 * *$ \\
\hline Invoeringswet (34986) & $29-06-2018$ & 07-03-2019 & 9 & $12-2019 ?$ & $8 * *$ \\
\hline Aanvw. natuur (34985) & $29-06-2018$ & 04-07-2019 & 12 & $03-2020 ?$ & $8 * *$ \\
\hline Aanvw. geluid (35054) & $05-10-2018$ & 02-07-2019 & 9 & $12-2019 ?$ & $5 * *$ \\
\hline Aanvw. grond (35133) & 01-02-2019 & $17-10-2019$ & 8,5 & $03-2020 ?$ & $5 * *$ \\
\hline Wijziging Awb (35256) & $10-07-2019$ & Nog niet & & & \\
\hline
\end{tabular}

heeft de Eerste Kamer al eerder laten weten het wenselijk te vinden de behandeling van de wetsvoorstellen synchroon te laten verlopen met de behandeling van de voorgehangen AMvB's. Ook heeft de Eerste Kamer laten weten dat deze wens op gespannen voet staat met de termijnen voortvloeiend uit de voorhangprocedure van art. 23.5 Omgevingswet.

Deze aflevering van Tijdschrift voor Omgevingsrecht is na 3 december 2019 verschenen. De lezer kan met de dán bekende brief van de Minister van Binnenlandse Zaken en Koninkrijksrelaties (BZK) tabel 1 aanpassen. ${ }^{8}$

\section{De onmogelijkheid om het systeem van de Omgevingswet te wijzigen}

De conclusie van Beurskens en Ypinga zal niet worden overgenomen. Ook al zou de regering het eens zijn met de conclusie, zij kan de aanbeveling niet overnemen. Al in het oorspronkelijk voorstel voor de Omgevingswet werd in art. 16.7 - met de toevoeging in de aanhef (toepassing coördinatieregeling Awb) - toepassing van afdeling 3.5 van de Awb voorgeschreven. ${ }^{9}$ Dat de coördinatieregeling geen onderdeel werd van de Omgevingswet zelf was toen al beslist en met de aanvaarding van de Omgevingswet was duidelijk dat een latere discussie over de plaats van de coördinatieregeling als gepasseerd station zou worden afgedaan. In zoverre had het de regering gesierd om in de memorie van toelichting duidelijk te maken dat de discussie over regeling in de Awb of de Omgevingswet geen rol meer kon spelen.

Het overnemen van de conclusie zou leiden tot ingrijpende wijziging van het voorstel tot wijziging van de

8. Op 1 november 2019 werd ook bekend dat niet minister Ollongren die brief zal ondertekenen. Dat zal worden gedaan door Van Veldhoven, de nieuwe Minister voor Milieu en Wonen.

9. Kamerstukken II 2013/14, 33 962, nr. 2.
Awb, want de gehele wijziging van afdeling 3.5 zou bij nota van wijziging (moeten) worden geschrapt. Maar bovendien zou de inhoud van art. 16.7 moeten worden gewijzigd en elke verwijzing naar afdeling 3.5 van de Awb er worden uit gehaald. Dat gaat de regering niet doen.

Daar is ook wel wat voor te zeggen, maar het geeft wel aan dat het vrij lastig is om een substantiële wijziging van de Omgevingswet door te voeren, omdat die wet zo innerlijk verknoopt is door de talrijke verwijzingen en de vantoepassingverklaringen dat een wijziging alleen al om redenen van complexiteit niet eens in overweging zal worden genomen. Dat geldt overigens voor tal van goede suggesties tot aanpassing van de Omgevingswet die gedaan zijn of zullen worden.

\section{Inhoud van deze aflevering van het Tijdschrift voor Omgevingsrecht}

Naast het hierboven al genoemde artikel van Nard Beurskens en Jelmer Y pinga, zijn verder artikelen opgenomen van Henk de Vries, Christine Visser, Ton Lavrijsen en Rieneke Jager.

Henk de Vries gaat in zijn artikel in op de betekenis van de 1 juli-uitspraken van de Centrale Raad van Beroep over de exceptieve toetsing van algemeen verbindende voorschriften. Bij zijn bespreking van die uitspraken gaat hij ook in op de ontwikkelingen die in de rechtspraak van de Afdeling bestuursrechtspraak van de Raad van State op het gebied van het omgevingsrecht zijn waar te nemen over het onverbindend verklaren of buiten toepassing laten van een algemeen verbindend voorschrift of een beleidsregel. Hij besluit zijn artikel met een vergelijking tussen de uitspraken van beide rechtscolleges. 
Christine Visser gaat in op de betekenis van de PAS-uitspraak voor de ADC-toets, namelijk op de vraag of maatregelen en autonome ontwikkelingen die blijkens de PAS-uitspraak niet mogen worden betrokken in de passende beoordeling op grond van art. 6, derde lid, van de Habitatrichtlijn wel een rol kunnen spelen in de ADCtoets op grond van art. 6, vierde lid, van de Habitatrichtlijn. Dit is een interessante vraag omdat dit (bij een positief antwoord) de haalbaarheid van deze oplossingsrichting (al dan niet door toepassing in een nieuw programma) kan vergroten.

Ton Lavrijsen bespreekt de voorgenomen inbouw van de waterveiligheidsnormen in het Besluit kwaliteit leefomgeving, een van de vier AMvB's onder de Omgevingswet. Hij gaat in op de parlementaire behandeling van de inbouw van de waterveiligheidsnormen in het stelsel van de Omgevingswet en de kwalificatie van de omgevingswaarden als resultaatsverplichting.

Rieneke Jager schetst in haar artikel de uitdaging dat om klimaatverandering tegen te gaan en de gaskraan in Groningen dicht te draaien - de circa 7 miljoen woningen in Nederland in 2050 aardgasvrij moeten zijn. De verantwoordelijkheid voor de transitie naar de aardgasvrije woonwijken ligt bij de gemeente, waarbij het de bedoeling is dat de gemeente in samenspraak met de woningeigenaren tot een oplossing komt. Zij beschrijft in haar bijdrage dat de gemeente nu nog geen verplichting tot afschakeling aan de woningeigenaren kan opleggen, maar wel een tweetal andere mogelijkheden heeft om de woonwijken stapsgewijs aardgasvrij te maken. Zij gaat ook in op de mogelijkheden die de gemeente heeft met het omgevingsplan op grond van de Omgevingswet. 